\title{
MEDIASI STRATEGI DALAM HUBUNGAN PEMBELAJARAN ORGANISASI TERHADAP KINERJA BISNIS
}

\author{
Fania Mutiara Savitri ${ }^{1}$ \\ Alfizi $^{2}$ \\ Im.Vanee@Gmail.Com ${ }^{1}$ \\ ${ }^{1}$ Fakultas Ekonomi Dan Bisnis Islam, Universitas Islam Negeri Walisongo, \\ Semarang \\ ${ }^{2}$ Fakultas Manajemen, Universitas Harapan Bangsa, Purwokerto
}

Diterima: Mei 2019, Disetujui: Juni 2019, Dipublikasikan: Juli 2019

\begin{abstract}
Business performance was always associated with small and medium scale businesses durability. Wedding Organizer (WO) Business was a seasonal business with poor durability characteristic due to wedding eventsfluctuation. The role of WO business was crucial in helping and organizing wedding event that isussualy needed by the bride and groom in wedding organizing. This study aimed to analyze the effect of organizational learning on business performance by collaboration and business diversification mediation in Semarang Wedding Organizer.

Research approach used quantitative methods. This research type is an explanatory research in explaining factors that affect business performance. This study took a sample of 43 respondents who run Wedding Organizer business in Semarang City by convenience sampling method. Data was collected through a questionnaire with a Likert scale measurement with five measurement scales. Data analysis method uses 3-stage multiple regression using SPSS 20.

The results of this study proved that organizational learning affects collaboration, organizational learning affectsbusiness performance; Organizational learning affectsbusiness diversification, collaboration affectsbusiness performance and diversification affectsbusiness performance. The mediation test also explained that collaboration and business diversification were successful as a mediating variable on research conducted at Semarang Wedding Organizer.
\end{abstract}

Keywords: Collaboration; Business Diversivication; Business Performance; Organizational Learning. 


\begin{abstract}
Abstrak
Kinerja bisnis seringkali dikaitkan dengan ketahanan bisnis skala kecil menengah. Bisnis wedding organizer (wo) merupakan bisnis musiman yang identik dengan daya tahan yang kurang baik karena fluktuasi peristiwa pernikahan. Peran bisnis wo ini sangat krusial dalam membantu jalannya acara pernikahan dan sebagai pengelola acara pernikahan yang seringkali dibutuhkan calon pengantin dalam menyelenggarakan acara pernikahan. Penelitian ini bertujuan untuk menganalisis pengaruh pembelajaran organisasi terhadap kinerja bisnis dengan mediasi kolaborasi dan diversifikasi usaha pada wedding organizer di kota semarang.

pendekatan penelitian yang digunakan menggunakan metode kuantitatif. Jenis penelitian ini merupakan penelitian eksplanatif dalam menjelaskan faktor yang mempengaruhi kinerja bisnis. Penelitian ini mengambil sampel sebanyak 43 responden yang yang menjalankan usaha wedding organizer di kota semarang dengan cara convenience sampling. Data dikumpulkan melalui kuesioner dengan pengukuran skala likert dengan lima skala pengukuran. Metode analisis data menggunakan regresi berganda 3 tahap menggunakan alat analisis spss 20 .

Hasil dari penelitian ini membuktikan bahwa pembelajaran organisasi berpengaruh terhadap kolaborasi, pembelajaran organisasi berpengaruh terhadap kinerja bisnis; pembelajaran organisasi berpengaruh terhadap diversifikasi usaha, kolaborasi berpengaruh terhadap kinerja bisnis dan diversifikasi usaha berpengaruh terhadap kinerja bisnis. Uji mediasi menjelaskan pula bahwa kolaborasi dan diversifikasi usaha berhasil terbukti sebagai variabel mediasi dalam penelitian yang dilakukan pada wedding organizer di kota semarang
\end{abstract}

Kata Kunci: Kolaborasi; Diversifikasi BisnisKinerja Bisnis; Pembelajaran Organisasi

\title{
PENDAHULUAN
}

Perkembangan ekonomi dunia serta perubahan struktural yang terjadi di berbagai segi dalam globalisasi, telah menimbulkan tantangan dan sekaligus peluang bagi perkembangan dunia usaha di pasar local maupun di pasar global. Satu hal yang merupakan prasyarat untuk dapat mengatasi tantangan yang ada dan memanfaatkan peluang bisnis yang timbul adalah meningkatkan daya saing. Daya saing strategi dicapai jika sebuah perusahaan berhasil merumuskan serta menerapkan suatu strategi yang tepat. Pada akhirnya isu permasalahan daya saing dapat teratasi. 
Ketidakmampuan suatu usaha dalam meningkatkan daya saing disebabkan karena usaha yang dijalankan memiliki berbagai keterbatasan, seperti kurangnya kemampuan untuk beradaptasi dengan lingkungan, kurang cekatan dalam peluang - peluang usaha, kurangnya kreativitas dan inovasi dalam mengantisipasi berbagai tantangan lingkungan. Disamping itu, secara internal kurang mempunyai kemampuan manajerial dan keterampilan dan kurangnya permodalan dan pasar. Disatu sisi, kajian literature menjelaskan bahwa terdapat tiga aspek kunci yang akan menentukan daya saing dan dapat berdampak pada kinerja perusahaan, yaitu factor lingkungan internal perusahaan, lingkungan eksternal dan wirausaha (Mustikowati, 2014).

Organisasi pada dasarnya seperti mahluk hidup yang kelangsungan hidupnya sangat ditentukan oleh kemampuannya untuk beradaptasi dengan lingkungan (Djamaludin, 2008 dalam Hasan, 2017). Organisasi dituntut untuk beradaptasi dengan cepat pada lingkungan strategic dengan dimensi teknologi, sosial, ekonomi, perundangan, dan globalisasi. Jika organisasi terlambat beradaptasi maka kinerja organisasi akan menurun. Pembelajaran organisasi dianggap sebagai salah satu komponen strategis dalam mencapai kesuksesan organisasi jangka panjang.

Pembelajaran organisasi merupakan proses dimana organisasi menggunakan pengetahuan yang ada dan membangun berbagai pengetahuan baru untuk membentuk pengembangan kompetensi baru yang sangat penting dalam lingkungan yang terus berubah. Kemampuan pembelajaran organisasi (organizational learning capability) dapat didefinisikan sebagai kemampuan organisasi untuk menerapkan praktek-praktek manajemen, struktur, sistem dan prosedur yang tepat dalam memfasilitasi dan memicu pembelajaran di organisasi tersebut. Proses pembelajaran organisasi ditujukan untuk peningkatan kinerja organisasi. Suatu perusahaan yang memiliki kemampuan pembelajaran organisasi akan lebih tanggap terhadap perubahan lingkungan. Selain itu perusahaan bisa melakukan tindakan secara tepat sehingga dapat meningkatkan keunggulan dalam bersaing. Oleh karena itu, kemampuan pembelajaran organisasi berpengaruh positif terhadap kinerja perusahan (Hasan, dkk., 2017). 
Telah banyak bukti yang menunjukkan bahwa sangat sulit untuk dapat berhasil menguasai pasar dengan kekuatan sendiri. Strategi melawan atau bergabung masih sering diterapkan oleh para pelaku bisnis. Di satu sisi melawan terlihat lebih berani, tetapi dengan konsekuensi menang atau hancur. Di sisi lain bergabung akan dirasa lebih lemah karena adanya kehilangan kendali. Dari dasar inilah maka tercipta fenomena strategi baru. Kedua elemen strategi tersebut dapat digabungkan untuk mendapatkan suatu nilai strategis yang saling menguntungkan, yaitu dengan aliansi strategis. Aliansi strategis tersebut adalah sebuah cara bagi pelaku usaha agar dapat menerobos hambatan pasar pada tingkat domestik, yaitu melakukan kerjasama dengan usaha lain atau perusahaan local tertentu. Aliansi tersebut merupakan cara yang tepat untuk menyetarakan diri, khususnya ketika mencari sumberdaya unik dan unggul (Hidayat, 2013).

Memandang dari sisi internal perusahaan, ketika perusahaan melakukan kolaborasi dengan pihak luar karena adanya spesialisasi bidang usaha, perlu juga untuk memperbaiki kondisi internal perusahaan. Salah satu cara yang di terapkan perusahaan dilevel korporat adalah diversifikasi usaha. Diversifikasi merupakan salah satu strategi yang dilakukan perusahaan untuk memperluas usahanya dengan membuka beberapa unit bisnis atau anak perusahaan baru baik dalam lini bisnis yang sama dengan yang sudah ada maupun dalam unit bisnis yang berbeda dengan bisnis inti perusahaan. Diversifikasi menjadi pilihan yang menarik bagi perusahan ketika perusahaan menghadapi persaingan yang sangat ketat dan pertumbuhan pasar yang cepat (Satoto, 2009).

Berbagai penelitian yang terkait dengan pengaruh pembelajaran organisasi terhadap kinerja usaha masih menunjukkan hasil yang berbeda. Penelitian yang dilakukan oleh Hasan, dkk., (2017) menunjukkan bahwa pembelajaran organisasi memberikan pengaruh yang positif terhadap kinerja usaha. Pengaruh tersebut berdampak langsung terhadap pertumbuhan penjualan dan pengembangan produk. Penelitian yang dilakukan oleh Hidayat (2013) juga menunjukkan bahwa kolaborasi memberikan pengaruh yang positif terhadap kinerja usaha. Penelitian oleh Nugraha (2017) pun juga mendukung bahwa ada dampak positif antara pembelajaran organisasi dengan kinerja bisnis. Namun penelitian yang dilakukan 
oleh Firdayanti, dkk., (2017) menunjukkan bahwa pembelajaran organisasional berpengaruh positif tidak signifikan terhadap kinerja bisnis. Pembelajaran organisasi yang dilakukan secara baik belum tentu juga akan menghasilkan kinerja bisnis yang baik pula.

Penelitian ini dilakukan pada salah satu jenis UMKM yang memiliki ketahanan yang kurang baik yaitu pada Wedding Organizer (WO). Permasalahan daya tahan bisnis WO mengindikasikan kinerja bisnis yang kurang baik sehingga perlu dikaji lebih lanjut. Usaha mikro kecil menengah yang bergerak dibidang WO sangat berperan dalam membantu penyelenggaraan pernikahan khususnya di kota Semarang. Dalam menjalankan usaha WO yang pada umumnya masih memiliki skala usaha kecil menengah, diperlukan adanya kemampuan berwirausaha yang baik agar dapat menunjang kinerja bisnis WO tersebut. Pelaku usaha dengan segenap tim diharapkan memahami pentingnya pembelajaran dalam organisasi dalam meningkatkan kinerja bisnisnya. Fenomena pra observasi menunjukkan ketidak handalan pendapatan yang diperoleh dari bisnis WO ini, sebanyak 59\% pelaku usaha mengatakan bahwa pendapatan dari WO tidak menentu ada tiap bulannya. Hal ini kurang sesuai dengan fenomena pernikahan yang terjadi di kota Semarang yakni berkisar 7000-8000 peristiwa dan hanya ditangani $11.7 \%$ oleh para pemimpin pasar bisnis WO ternama di Semarang. Artinya peluang pasar bisnis WO masih sangat luas. Fenomena tersebut mengindikasikan bahwa kinerja bisnis WO kurang optimal sehingga patut untuk dikaji.

Adanya inkonsistensi hasil penelitian terdahulu menunjukkan hasil yang berbeda (research gap) antara pengaruh pembelajaran organisasi terhadap kinerja bisnis. Penelitian Hasan, dkk., (2017), Hidayat (2013) dan Nugraha (2017) membuktikan adanya pengaruh pembelajaran organisasi terhadap kinerja bisnis sementara Firdayanti, dkk (2017) membuktikan tidak adanya pengaruh pembelajaran organisasi terhadap kinerja bisnis. Adanya inkonsistensi antara hubungan pembelajaran organisasi dengan kinerja bisnis tersebut maka penulis ingin mengkaji penelitian mengenai kinerja bisnis WO di Semarang dengan variabel mediasi kolaborasi dan diversifikasi usaha untuk mengisi adanya kesenjangan penelitian. 
Berdasarkan fenomena dan kesenjangan riset, yang menjadi masalah dalam penelitian adalah: bagaimana membangun sebuah model penelitian yang dapat mengoptimalkan kinerja bisnis WO sehingga hasil dari usaha yang telah dibangun dapat diandalkan sesuai dengan yang diharapkan. Berdasarkan uraian latar belakang masalah tersebut, maka tujuan penelitian sebagai berikut:

1. Untuk menguji secara empiris pengaruh pembelajaran organisasi terhadap kolaborasi weeding organizer di kota Semarang.

2. Untuk menguji secara empiris pengaruh pembelajaran organisasi terhadap kinerja bisnis weeding organizer di kota Semarang.

3. Untuk menguji secara empiris pengaruh pembelajaran organisasi terhadap diversifikasi usaha weeding organizer di kota Semarang.

4. Untuk menguji secara empiris pengaruh kolaborasi terhadap kinerja bisnis weeding organizer di kota Semarang.

5. Untuk menguji secara empiris pengaruh diversifikasi usaha terhadap kinerja bisnis weeding organizer di kota Semarang.

\section{TELAAH PUSTAKA}

Merujuk pada triadic reciprocal (Bandura \& Walters, 1977) ada tiga faktor yang saling mempengaruhi dalam proses pembelajaran yaitu personal determinants, behavioral determinants, dan environmental determinants. Proses timbal balik inilah yang melandasi peningkatan kinerja dari suatu pembelajaran yang dikenal dengan pembelajaran sosial.

Perusahaan memiliki tujuan mencapai keunggulan kompetitif yang bedayatahan. Bagi Barney, keberadaan sumber daya yang potensial bermanfaat bagi organisasi dalam menjalankan sebuah strategi guna mencapai keunggulan kompetitif. Barney (2001) menjelaskan bahwa keuntungan dari memposisikan pandangan berbasis sumberdaya relative terhadap mikro ekonomi neo-klasik sangat signifikan sebagaimana Barney menjelaskan inti dariResouce based view itu sendiri: 
The concept of strategic factor markets is introduced, and it is shown that when these markets are perfectly competitive, acquiring the resources necessary to create imperfectly competitive product markets will absorb all the profits that this imperfect competition would otherwise create. Thus, for firms to obtain economic rents, they must acquire the resources and capabilities needed to conceive of and implement strategies in imperfectly competitive strategic factor markets.

\section{Pengaruh Pembelajaran Organisasi terhadap Kolaborasi}

Pembelajaran organisasi dibangun dengan dasar moral maupun material seperti beberapa indikasi dan faktor yang telah dibahas sebelumnya, maka kinerja bisnis perusahaan diantara perusahaan dan pemasok diyakini akan ikut terdongkrak pula karena suatu kepercayaan adalah dasar yang harus dimiliki sebelum dilakukannya kegiatan berbagi informasi dan pengintegrasian proses antar organisasi (Hasan., dkk.,2017).

Semakin baik pembelajaran organisasi suatu usaha maka semakin baik kualitas kolaborasi yang dijalankan dan sebaliknya semakin rendah pembelajaran organisasi suatu usaha maka semakin rendah kualitas kolaborasi yang dijalankan. Rani, et all (2017) Koordinasi dan kepercayaan yang merupakan komponen pembelajaran dalam organisasi berpengaruh signifikan terhadap kolaborasi.Berdasarkan uraian tersebut, maka hipotesa dalam penelitian ini adalah sebagai berikut:

H1: Semakin baik pembelajaran organisasi maka semakin mendorong kolaborasi.

\section{Pengaruh Pembelajaran Organisasi terhadap Kinerja Bisnis}

Hasan, dkk., (2017) dalam penelitiannya mendapatkan bahwa komitmen manajerial, system perspektif, keterbukaan dan percobaan, serta perpindahan pengetahuan dan pengintegrasian memiliki hubungan yang signifikan terhadap pembelajaran organisasi. Komitmen manajerial merupakan aktivitas manajerial yang efektif mulai dari perencanaan, pelaksanaan, penata usahaan dan laporan. 
Semakin tinggi tingkat komitmen manajerial maka akan semakin tinggi pula kinerja bisnis tersebut. Sistem perspektif merupakan sudut pandang seseorang terkait dengan suatu hal atau masalah tertentu. Semakin baik system perspektif suatu perusahaan maka akan semakin baik pula kinerja bisnis tersebut. Keterbukaan merupakan ketersediaan untuk memberikan informasi mengenai berbagai hal yang berkaitan dengan bisnis. Sedangkan percobaan merupakan serangkaian kegiatan dimana setiap tahap dalam rangkaian benar-benar disampaikan dengan baik agar menemukan jawaban atas permasalahan dalam suatu bisnis. Semakin tinggi tingkat keterbukaan dan percobaan maka akan semakin baik pula kinerja bisnis tersebut. Tujuan dari adanya perpindahan pengetahuan dan pengintegrasian adalah untuk memanfaatkan karyawan agar mereka mau bekerja keras dan berpartisipasi aktif dalam menunjang tercapainya tujuan bisnis. Semakin tinggi tingkat perpindahan pengetahuan dan pengintegrasian maka akan semakin tinggi pula kinerja bisnis tersebut.

Temuan pengaruh positif pembelajaran organisasi terhadap kinerja bisnis didukung oleh penelitian Hasan, dkk (2017) dan Sirait, dkk (2015) yang menyatakan bahwa pembelajaran organisasi berpengaruh positif terhadap kinerja UMKM. Berdasarkan uraian tersebut, maka hipotesa dalam penelitian ini adalah sebagai berikut:

H2 : Semakin baik pembelajaran organisasi maka semakin baik kinerja bisnis.

\section{Pengaruh Pembelajaran Organisasi terhadap Diversifikasi}

Semakin baik pembelajaran organisasi pada suatu usaha/ bisnis tertentu maka kecenderungan dalam mengimplementasikan diversifikasi usaha semakin tinggi bahkan ketika organisasi mampu belajar dengan baik dan usaha yang di kelola suatu organisasi sudah memiliki diversifikasi usaha tertentu maka dapat meningkatkan efektifitas dari diversifikasi usaha tersebut. Sebaliknya jika pembelajaran organisasi rendah, maka implementasi dan efektifitas diversifikasi usaha akan rendah pula.

Penelitian Hitt, et all (2016) mengungkapkan bahwa pembelajaran organisasi adalah proses incremental penting yang menghasilkan diversifikasi 
skala internasional. Autio et al., (2000) dalam Hitt, et all, (2016) juga mengkapkan bahwa pembelajaran organisasi merupakan antesenden dalam memahami diversifikasi usaha. Berdasarkan uraian tersebut, maka hipotesa dalam penelitian ini adalah sebagai berikut :

H3 : Semakin baik pembelajaran organisasi maka semakin baik diversifikasi usaha.

\section{Pengaruh Kolaborasi terhadap Kinerja Bisnis}

Kinerja dan penciptaan keunggulan bersaing berkelanjutan dapat dimaksimalkan dengan kolaborasi (Nugroho, 2017). Hubungan kerjasama dengan pemasok sangat berperan menentukan kinerja bisnis perusahaan. Untuk mendapatkan kinerja yang baik melalui sebuah kerjasama, hubungan antara kedua belah pihak mutlak diperlukan. Kejujuran (honesty) menjadi salah satu pertimbangan penting dalam penentuan model rating pemasok.

Rani, et all (2017) Mengungkapkan bahwa dalam menghadapi tantangan yang terjadi dan persaingan yang semakin ketat tersebut, mengharuskan setiap bisnis untuk meningkatkan keunggulan kompetitifnya agar tetap mampu bersaing, salah satunya melalui kolaborasi dengan supplier. Kolaborasi merupakan kekuatan penggerak di balik manajemen rantai pasok yang efektif. Keberhasilan kolaborasi dan kemitraan dengan pemasok maupun pelanggan, akan mengarah pada perbaikan kinerja keseluruhan.

Uraian di atas relevan dengan temuan Nugroho (2017). Berdasarkan uraian tersebut, maka hipotesa dalam penelitian ini adalah sebagai berikut :

H4: Semakin baik kolaborasi maka kinerja bisnis akan semakin meningkat.

\section{Pengaruh Diversifikasi terhadap Kinerja Bisnis}

Sari dkk (2014) mengungkapkan bahwa berbagai kajian dan pendapat masih memperdebatkan apakah kebijakan diversifikasi dapat membawa manfaat ataupun justru membawa dampak negative terhadap keunggulan kompetitif dalam jangka panjang. Ada pendapat yang menganggap bahwa strategi fokus pada 
kompetensi inti justru merupakan kunci utama terhadap keunggulan perusahaan dalam jangka panjang, namun ada pula yang berpendapat bahwa perusahaan yang terdiversifikasi justru akan meningkatkan kinerja perusahaan. Semakin baik diversifikasi usaha yang dilakukan oleh perusahaan maka kinerja bisnisnya akan meningkat Sebaliknya apabila semakin kurang baik diversifikasi usaha yang dilakukan oleh perusahaan maka kinerja bisnisnya akan stagnan dan cenderung menurun.

Kurniawan (2012) mengatakan bahwa kinerja usaha secara positif dan signifikan dipengaruhi oleh strategi diversifikasi. Hal lain membuktikan pula bahwa penyertaan diversifikasi usaha dapat mempengaruhi kinerja bisnis (Hashai, 2015). Penelitian ini sejalan dengan penelitian Visnjic., et al, (2016) yang membuktikan bahwa diversifikasi produk suatu perusahaan yang diukur dalam suatu indek dapat mempengaruhi margin laba yang diperoleh dimana margin laba merupakan salah satu indicator dalam kinerja suatu usaha. Berdasarkan hipotesis uraian di atas maka dirumuskan hipotesis penelitian sebagai berikut:

H5: Semakin baik diversifikasi usaha maka kinerja bisnis akan semakin meningkat.

\section{METODE}

\section{Pengumpulan Data}

Penelitian ini menggunakan data primer. Metode pengumpulan data yang akan digunakan dalam penelitian ini adalah pengisian kuesioner secara perseorangan pada pelaku usaha WO di Semarang. Teknik ini memberikan tanggungjawab kepada masing - masing responden untuk menjawab setiap pertanyaan yang diajukan oleh peneliti. Setelah mendapatkan penjelasan mengenai item pertanyaan yang diajukan, diperoleh sampel sebanyak 43 responden.

\section{Analisis Data}

Analisis regresi linier berganda digunakan untuk mengetahui ada tidaknya pengaruh antara variable independen dan variable mediasi terhadap variable dependen. Model hubungan dengan variabel-variabel tersebut dapat disusun dalam fungsi atau persamaan sebagai berikut: 
I. $\quad \mathrm{M} 1=\alpha+\beta 1 \mathrm{X} 1+\mathrm{e}$

II. $\quad \mathrm{Y}=\alpha+\beta 1 \mathrm{X} 1+\beta 2 \mathrm{M} 1+\beta 3 \mathrm{M} 2+\mathrm{e}$

III. $\mathrm{M} 2=\alpha+\beta 1 \mathrm{X} 1+\mathrm{e}$

Di mana:

$\begin{array}{ll}\mathrm{Y} & : \text { Kinerja Bisnis } \\ \mathrm{X} & : \text { Pembelajaran Organisasi } \\ \mathrm{M} 1 & : \text { Kolaborasi } \\ \mathrm{M} 2 & : \text { Diversifikasi Usaha } \\ \beta 1 \ldots \beta 3 & : \text { Koefisien regresi variable independen } \\ e & : \text { Kesalahan estimasi }\end{array}$

Hasil dan Pembahasan

\section{Statistik Deskriptif}

Hasil uji validitas menunjukan bahwa item pertanyaan menunjukan Pembelajaran organisasi, Kolaborasi usaha, dan Diversifikasi usaha dan variable Kinerja Bisnis dalam kuisioner adalah valid. Hal ini dibuktikan dengan nilai rhitung> r-tabel (0.2512). hal ini dapat diartikan bahwa indikator tepat sebagai pengukur konstruk sesuai yang dipersyaratkan.

Berdasarkan hasil pengujian reliabilitas menunjukkan bahwa semua variabel yang dijadikan sebagai instrument adalah reliable atau dapat dipercaya dan konsisten dari waktu ke waktu. Reliabiltas instrumen yang semakin tinggi, menunjukkan hasil ukur yang didapatkan semakin terpercaya. Hal ini dapat dibuktikan dengan nilai koefisien $\boldsymbol{\alpha}$ lebih besar dari 0,6. 


\section{Uji Asumsi Klasik}

Berdasarkan tampilan output SPSS, hasil regresi memiliki nilai Asymp. Sig Kolmogorov-Smirnov lebih dari 0,05. Hal ini menandakan bahwa variabel kinerja bisnis pada regresi terdistribusi secara normal. Serta tidak ada indikasi multikolinieritas, karena nilai tolerance lebih dari 0.1 dan VIF dari semua variabel kurang dari 10.

Uji glejser menunjukkan homogenitas dari nilai signifikasi yang lebih dari 0,05. Hasil uji tersebut mengindikasikan bahwa tidak ada heteroskedastisitas dalam model regresi.

\section{Analisis Regresi Berganda}

Tabel 7. Hasil Regresi Berganda I

\begin{tabular}{|c|c|c|c|c|c|}
\hline \multirow[t]{2}{*}{ Model } & \multicolumn{2}{|c|}{$\begin{array}{l}\text { Unstandardized } \\
\text { Coefficients }\end{array}$} & \multirow{2}{*}{$\begin{array}{l}\text { Standardize } \\
\mathrm{d} \\
\text { Coefficient } \\
\mathrm{s} \\
\text { Beta }\end{array}$} & \multirow[t]{2}{*}{$\mathrm{T}$} & \multirow[t]{2}{*}{ Sig. } \\
\hline & B & Std. Error & & & \\
\hline (Constant) & 9,600 & 2,123 & & 4,522 & 000, \\
\hline $\begin{array}{l}\text { PembelajaranOrga } \\
\text { nisasi }\end{array}$ &, 576 & ,068 & ,799 & 8,493 & ,000 \\
\hline
\end{tabular}

a. Dependent Variable: Kolaborasi

Sumber: data primer diolah, 2018

"Kolaborasi $=0.799$ PembelajaranOrganisasi" 
Tabel 8 Hasil Regresi Berganda II

\begin{tabular}{|c|c|c|c|c|c|}
\hline \multirow[t]{2}{*}{ Model } & \multicolumn{2}{|c|}{$\begin{array}{l}\text { Unstandardized } \\
\text { Coefficients }\end{array}$} & \multirow{2}{*}{\begin{tabular}{|l}
$\begin{array}{l}\text { Standardize } \\
\text { d } \\
\text { Coefficient } \\
\text { s }\end{array}$ \\
Beta
\end{tabular}} & \multirow[t]{2}{*}{$\mathrm{t}$} & \multirow[t]{2}{*}{ Sig. } \\
\hline & B & $\begin{array}{l}\text { Std. } \\
\text { Error }\end{array}$ & & & \\
\hline (Constant) & 1,363 & 1,034 & & 1,318 & , 195 \\
\hline $\begin{array}{l}\text { PembelajaranOrga } \\
\text { nisasi }\end{array}$ & ,314 & ,052 & ,490 & 5,996 & ,000 \\
\hline Diversifikasi &, 259 & ,087 & ,268 & 2,966 & ,005 \\
\hline Kolaborasi &, 237 & 071 & ,266 & 3,312 & ,002 \\
\hline
\end{tabular}

a. Dependent Variable: Kinerja

Sumber: data primer diolah, 2018

“Kinerja Bisnis $=0.490$ Pembelajaran Organisasi+ 0.268 Diversifikasi +0.266 Kolaborasi”

Tabel9.Hasil RegresiBerganda III

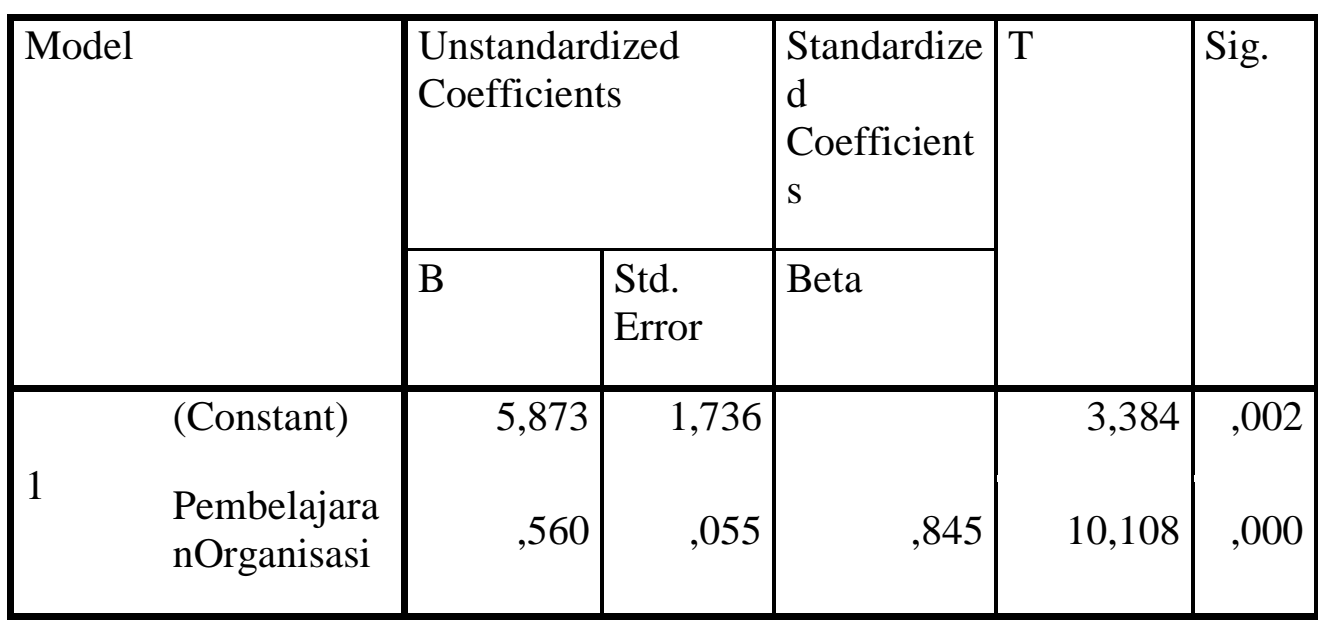

a. Dependent Variable: Diversifikasi

Sumber: data primer diolah, 2018

"Diversifikasi $=0.845$ Pembelajaran Organisasi" 


\section{Uji Hipotesis}

Dari ketiga persamaan regresi diatas dapat ditarik kesimpulan sebagai berikut:

1. Variabel Pembelajaran organisasi berpengaruh terhadap Kolaborasi. Hal ini dibuktikan dengan nilai statistik sebesar 0,000 yang $<0.05$. Dengan demikian sesuai dengan hipotesis awal (H1) yang menyatakan semakin baik pembelajaran organisasimaka semakin baik kecenderungan melakukan kolaborasi usaha (H1 diterima).

2. Pembelajaran organisasi berpengaruh terhadap Kinerja Bisnis. Hal ini dibuktikan dengan nilai statistik sebesar 0,000yang $<0.05$. Dengan demikian sesuai dengan hipotesis awal (H2) yang menyatakan bahwa semakin baik pembelajaran organisasi semakin meningkatkan Kinerja Bisnis (H2 diterima).

3. Variabel Pembelajaran organisasi berpengaruh terhadap Diversifikasi usaha. Hal ini dibuktikan dengan nilai statistik sebesar 0,000 yang $<0.05$. Dengan demikian sesuai dengan hipotesis awal (H3) yang menyatakan semakin baik pembelajaran organisasimaka semakin baik kecenderungan melakukan diversifikasi usaha (H3 diterima).

4. Kolaborasi berpengaruh terhadap Kinerja Bisnis. Hal ini dibuktikan dengan nilai statistik sebesar 0,002yang $<0.05$. Dengan demikian sesuai dengan hipotesis awal (H4) yang menyatakan bahwa semakin baik kolaborasi usaha semakin meningkatkan Kinerja Bisnis (H4diterima).

5. Diversifikasi usaha berpengaruh terhadap Kinerja Bisnis. Hal ini dibuktikan dengan nilai statistik sebesar 0,005yang $<0.05$. Dengan demikian sesuai dengan hipotesis awal (H5) yang menyatakan bahwa semakin baik Diversifikasi semakin meningkatkan Kinerja Bisnis (H5diterima). 


\section{Koefisien Determinan}

Koefisien Determinasi $\left(R^{2}\right)$ untuk mengetahui tingkat ketepatan paling baik dalam analisa regresi dimana hal yang ditunjukan oleh besarnya koefisien determinasi ( $R^{2}$ ) antara 0 ( nol ) dan 1 ( satu ).

Tabel 10. Koefisien Determinasi I

Model Summary ${ }^{\mathrm{b}}$

\begin{tabular}{|l|r|r|r|r|r|}
\hline Model & R & R Square & $\begin{array}{l}\text { Adjusted R } \\
\text { Square }\end{array}$ & $\begin{array}{l}\text { Std. Error of } \\
\text { the Estimate }\end{array}$ & Durbin-Watson \\
\hline 1 &, $799^{\text {a }}$ &, 638 &, 629 & 2,13244 & 1,299 \\
\hline
\end{tabular}

a. Predictors: (Constant), Pembelajaran Organisasi

b. Dependent Variable: Kolaborasi

Sumber : Data Primer yang diolah, 2018

Tabel 11. Koefisien Determinasi II

Model Summary ${ }^{\mathrm{b}}$

\begin{tabular}{|l|l|r|l|l|l|}
\hline Model & R & R Square & $\begin{array}{l}\text { Adjusted R } \\
\text { Square }\end{array}$ & $\begin{array}{l}\text { Std. Error of the } \\
\text { Estimate }\end{array}$ & Durbin-Watson \\
\hline 1 &, $966^{\mathrm{a}}$ &, 933 &, 927 &, 83819 & 2,144 \\
\hline
\end{tabular}

a. Predictors: (Constant), Kolaborasi, Pembelajaran Organisasi, Diversifikasi

b. Dependent Variable: Kinerja

Sumber : Data Primer yang diolah, 2018 
Tabel12. Koefisien Determinasi III

Model Summary

\begin{tabular}{|c|c|c|c|c|c|}
\hline Model & $\mathrm{R}$ & R Square & $\begin{array}{l}\text { Adjusted R } \\
\text { Square }\end{array}$ & $\begin{array}{l}\text { Std. Error of the } \\
\text { Estimate }\end{array}$ & Durbin-Watson \\
\hline 1 &, $845^{\mathrm{a}}$ & ,714 & ,707 & 1,74330 & 1,942 \\
\hline
\end{tabular}

a. Predictors: (Constant), PembelajaranOrganisasi

b. Dependent Variable: Diversifikasi

Sumber : Data Primer yang diolah, 2018

Dari ketiga persamaan tersebut, perolehan koefisien determinasi agar membentuk model kesatuan penelitian ini dihitung dalam peritungan sebagai berikut:

1. Menghitung e1 pada persamaan III $\left(1-\mathrm{R}^{2}\right)=\left(1-0,629^{2}\right)=0,604$

2. Menghitung e2 pada persamaan $I\left(1-R^{2}\right)=\left(1-0,927^{2}\right)=0,140$

3. Menghitung e3 pada persamaan II $\left(1-\mathrm{R}^{2}\right)=\left(1-0,707^{2}\right)=0,500$

4. Total $\mathrm{R} 2=1-(\mathrm{e} 1 \times \mathrm{e} 2 \mathrm{x}$ e3 $)=1-(0,604 \times 0,140 \times 0,500)=0,957$

Dari R Square total senilai 0,957 atau $95,7 \%$ dapat diartikan bahwa faktor-faktor yang mempengaruhi kinerja bisnis dalam penelitian ini, variable independennya memiliki pengaruh besar terhadap variable dependennya.

\section{Uji Sobel}

Berdasarkan perhitungan Uji sobel untuk menguji variabel intervening kolaborasi dan diversivikasi, didapatkan hasil efek mediasi sebagai berikut: 
Tabel 13. Sobel Test

\begin{tabular}{lll}
\multicolumn{1}{c}{ Test Name } & Test statistic & P value \\
\hline Sobel Test Kolaborasi & 3.56943 & 0.00036 \\
Aroian Test Kolaborasi & 3.55775 & 0.00037 \\
Sobel Test Diversifikasi & 3.02035 & 0.00252 \\
Aroian Test Diversifikasi & 3.01421 & 0.00258
\end{tabular}

Sumber: Data Primer Diolah, 2018

Berdasarkan tabel, terlihat bahwa test-Statistik berada lebih rentang 1,96 dan tingkat signifikasi> 0,05 sehingga terbukt isebagai variable mediasi antara pembelajaran organisasi terhadap kinerja bisnis. Berarti kolaborasi dan diversifikasi usaha mampu menjadi perantara pembelajaran organisasi terhadap kinerja bisnis. Apabila pembelajaran organisasi secara parsial sudah dapat meingkatkan kinerja bisnis, ketika ditambahkan mediasi implementasi strategi kolaborasi dan strategi diversifikasi, kinerja bisnis akan lebih optimal.

\section{HASIL}

\section{Pembelajaran organisasi berpengaruh terhadap Kolaborasi}

Variabel Pembelajaran organisasi berpengaruh terhadap Kolaborasi. Dalam teoripembelajaransosialdimanaperilakudipengaruhi oleh personal dan lingkungan personal dapat diasumsikan sebagai individu sementara lingkungan dapat pula diasumsikan sebagai sebuah organisasi. Individu yang melakukan proses pengintegrasian, perpindahan pengetahuan dan roses pembelajaran dalam menjalankan sebuah organisasi nantinya akan mempengaruhi sikap dalam menjalankan suatu pekerjaan. Bagaimana individu berperilaku dalam sebuah organisasi dipengaruhi oleh respon evaluative dari pembelajaran. Tujuannya 
untuk menjadi organisasi yang lebih kompetitif baik denga nmenjalankan strategi bersaing maupun strategi berkerjasama. Kolaborasi juga menjadi alternative mekanisme usaha untuk memperoleh akses, modal, keahlian, dan sumberdaya langka. Dalam konteks bisnis merupakan mekanisme terbaik kerjasama antar organisasi jika organisasi ingin memperoleh apa yang menjadi tujuannya. Kolaborasi dilukiskan sebagai situasi menang-menang, melalui sinergi dalam sebuah aliansi dan mitra yang saling melengkapi (komplementer). Proses individu menemukan mekanisme yang tepat dalam berkolaborasi adalah dengan melakukan pembelajaran organisasi yang berhasil. Sejalan dengan penelitian Hitt, et all (2016) yang mengungkapkan bahwa pembelajaran organisasi adalah proses incremental penting yang menghasilkan diversifikasi skala internasional, penelitian ini juga membuktikan hal yang senada bahwa pembelajaran organisasi memberikan pengaruh pada kecenderungan dan implementasi diversifikasi usaha.Autio et al., (2000) dalam Hitt, et all, (2016) juga mengungkapkan bahwa pembelajaran organisasi merupakan antesenden dalam memahami diversifikasi usaha.

\section{Pembelajaran organisasi berpengaruh terhadap Kinerja Bisnis}

Pembelajaran organisasi berpengaruh terhadap Kinerja Bisnis. Empat perspektif dalam system pengukuran kinerja dimana salah satunya adalah perspektif Pertumbuhan dan Pembelajaran mengidentifikasi infrastruktur yang harus dibangun perusahaan dalam menciptakan pertumbuhan dan peningkatan kinerja jangka panjang. Hal yang bias dilakukan oleh UMKM dalam perspektif ini adalah dengan melatih para pekerja, meningkatkan teknologi dan sistem informasi serta menyelaraskan berbagai prosedur dan kegiatan bisnis sehari-hari. Di dalam pembelajaran organisasi, individu-individu yang ada dalam bisnis akan terus meningkatkan kemampuan mereka dengan terus belajar dan saling berbagi pengetahuan satu sama lain mengenai informasi maupun proses produksi yang lebih baik sehingga dapat meningkatkan kinerja bisnis (Hasan, dkk., 2017). Temuan ini sejalan dengan temuan Nugraha (2017) yang membuktikan semakin tinggi pembelajaran organisasi pada bisnis tertentu maka akan mengakibatkan 
kinerja pada bisnis tersebut semakin baik. Pengaruh positif pembelajaran organisasi terhadap kinerja bisnis didukung oleh penelitian Hasan (2017) dan Sirait, dkk (2015) yang menyatakan bahwa pembelajaran organisasi berpengaruh positif terhadap kinerja UMKM.

\section{Pembelajaran organisasi berpengaruh terhadap Diversifikasi Usaha}

Variabel Pembelajaran organisasi berpengaruh terhadap Diversifikasi usaha. Individu dalam organisasi diharapkan mampu menemukan kompetensi inti yang dapat digunakan dalam organisasinya guna memenangkan persaingan usaha. Namun lebih jauh lagi, organisasi diharapkan mampu mengeksplore dan meningkatkan kompetensi serta kemampuan yang dimiliki dalam menghadapi perkembangan dunia usaha yang selalu berubah secara dinamis. Penemuan kompetensi dan kemampuan baru ini diperoleh dari pembelajaran dalam organisasi. Kemampuan baru organisasi berdampak pada implementasi perluasan usaha yang dikenal dengan istilah diversifikasi. Manfaat Diversifikasi usaha Menurut Tjiptono (2016) menjelaskan tentang manfaat diversifikasi usaha yaitu perusahaan dapat mengerahkan full capacity karena tidak tergantung pada satu macam produk/jasa. Dapat memaksimumkan profitnya dengan cara mengadakan ekspansi. Penemuan-penemuan baru yang menguntungkan bagi calon konsumen. Dengan mengadakan diversifikasi usaha, perusahaan tidak bergantung pada satu pasar saja. Hasil penelitian ini sejalan dengan penelitian Hittet all (2016). Penelitian Hitt, et all (2016) mengungkapkan bahwa pembelajaran organisasi adalah proses incrementa lpenting yang menghasilkan diversifikasi skala internasional. Autio et al., (2000) dalam Hitt, et all, (2016) juga mengungkapkan bahwa pembelajaran organisasi merupakan faktor penting dalam memahami diversifikasi.

\section{Kolaborasi berpengaruh terhadap Kinerja Bisnis}

Kolaborasi berpengaruh terhadap Kinerja Bisnis. Perusahaan memiliki tujuan mencapai keunggulan kompetitif yang berdayatahan. Bagi Barney (2001), keberadaan sumberdaya yang potensial bermanfaat bagi organisasi dalam 
menjalankan sebuah strategi guna mencapai keunggulan kompetitif. Keunggulan kompetitif tersebut diperoleh dari evaluasi kinerja yang baik ditinjau dari segala aspeknya. Pandangan sumberdaya bagi Barney yang menjelaskan bahwa pentingnya sumberdaya yang dapat menjalankan sebuah strategi dapat meningkatkan kinerja yang akhirnya dapat menyerap keuntungan. Strategi kolaborasi merupakan suatu contoh strategi bisnis yang memerlukan sumberdaya potensial sebagai motor dalam implementasi strategi. Peningkatan kinerja bisnis dipicu oleh kecenderungan kolaborasi yang dilakukan oleh suatu usaha dan sebaliknya ketika suatu usaha tidak melakukan kolaborasi maka akan cenderung stagnan atau bahkan bias menurun. Sejalan dengan Rani, et all (2017), dalam penelitiannya ketika menghadapi tantangan yang terjadi dan persaingan yang semakin ketat tersebut, mengharuskan setiap bisnis untuk meningkatkan keunggulan kompetitifnya agar tetap mampu bersaing, salah satunya melalui kolaborasi dengan supplier.Penelitian ini sejalan juga dengan Nugroho (2017) yang mengatakan bahwa kolaborasi dapat mempengaruhi kinerja.

\section{Diversifikasi usaha berpengaruh terhadap Kinerja Bisnis}

Diversifikasi usaha berpengaruh terhadap Kinerja Bisnis. Dengan demikian semakin baik Diversifikasi semakin meningkatkanKinerja Bisnis. Semakin rendah tingkat kolaborasi yang dilakukan pelaku usaha maka semakin rendah kinerja bisnisnya khusunya pada bisnis WO.Tjiptono (2016) mengemukakan bahwa Resouce Based memunculkan sejumlah prediktor potensial kelanggengan bisnis, diantaranya faktor internal berupa strategi bisnis. ResourceBased Theory merupakan sumber daya perusahaan bersifat heterogen dan jasa produktif yang berasal dari sumber daya perusahaan memberikan karakter unik bagi tiap-tiap perusahaan. Sumber daya yang heterogen tersebut diaplikasikan dalam keragaman jasa WO. Sebuah bisnis jasa organizer memerlukan banyak vendor sebagai pelengkap kebutuhan mengorganisasikan sebuah event. Untuk meminimalkan cost baiknya usaha WO tersebut memperluas bidang usaha baik yang sebidang maupun lain bidang namun masih terkait dari sisi pelanggan. Diversifikasi menjadi sebuah strategi pemenuhan kebutuhan konsumen yang terus 
berkembang secara dinamis.Kurniawan (2012) mengatakan bahwa kinerja usaha secara positif dan signifikan dipengaruhi oleh strategi diversifikasi. Hal lain membuktikan pula bahwa penyertaan diversifikasi usaha dapat mempengaruhi kinerja bisnis (Hashai, 2015), ketiga peneliti diatas mendukung hasil penelitian ini.Penelitian ini sejalan dengan penelitian Visnjic., et al, (2016) yang membuktikan bahwa diversifikasi produk suatu perusahaan yang dapat mempengaruhi margin laba yang diperoleh dimana margin laba merupakan salah satu indikator dalam kinerja suatu usaha.

\section{PENUTUP}

Hasil penelitian membuktikan bahwa pengujian yang dilakukan mampu menjelaskan dan menjawab rumusan masalah melalui bangunan sebuah model penelitian yang dapat mengoptimalkan kinerja bisnis WO sehingga hasil dari usaha yang telah dibangun dapat diandalkan sesuai dengan yang diharapkan.

Implikasi teoritis yang terdapat dalam penelitian ini antara lain Pembelajaran organisasi dapat mempengaruhi kolaborasi usaha. Individu yang mampu belajar dengan terus mencari pengetahuan baru yang bermanfaat untuk organisasinya dan mampu mengevaluasi keterbatasan usaha maka individu tersebut cenderung melakukan strategi bisnis salah satunya dengan berkolaborasi (Hitt, et al. 2016), Kinerja bisnis dipengaruhi oleh Pembelajaran Organisasi. Individu yang memiliki kemampuan pembelajaran organisasi yang baik pasti akan mampu meningkatkan kinerja bisnisnya. Penelitian ini konsisten dengan penelitian Nugraha (2017),Hasan (2017) dan Sirait, dkk (2015), Pembelajaran organisasi dapat mempengaruhi kecenderungan diversifikasi yang sesuai dengan penelitian Autio et al., (2000) dalam Hitt, et al, (2016), Kinerja bisnis dipengaruhi oleh kolaborasi usaha. Dalam tingkat persaingan yang tinggi kolaborasi usaha dapat menutup kekurangan suatu bisnis dan menjadi pelengkap dari kompetensi inti yang dimiliki oleh suatu bisnis. Penelitian ini konsisten dengan penelitian Rani, et all (2017) dan Nugroho (2017).Kinerja bisnis dipengaruhi oleh diversifikasi usaha.Tidak selamanya usaha yang fokus pada kompetensi inti dapat mengembangkan bisnisnya. Ketika suatu usaha dihadapkan pada perubahan lingkungan yang dinamis, keragaman permintaan konsumen dan 
adanya peluang perluasan usaha yang memiliki prospek baik maka kecenderungan usaha melakukan diversifikasi semakin tinggi. Penelitian ini konsisten dengan yang konsisten dengan penelitian, Hashai (2015), Visnjic., et al, (2016) dan Kurniawan (2012).

Implikasi manajerialVariabel pembelajaran organisasi berpengaruh terhadap kolaborasi. Kekurang andalan pendapatan WO umumnya disebabkan karena jaringan bisnis yang sempit. Tingkat repeat order kecil atau bahkan tidak ada. Ketika pemilik WO memiliki pandangan dan menyadari kekurangan membangun jaringan pemasaran yang luas, ada baiknya WO melakukan kolaborasi dengan WO lainnya untuk mendapatkan $s u b$ job ataupun dengan usaha lain yang terkait dengan bisnis ini seperti usaha catering, fotografi dan sebagainya. Variabel Pembelajaran organisasi mempengaruhi Kinerja Bisnis, hal ini menjadi perhatian pimpinan usahaWO dan karyawan agar mulai memperhatikan selera klien dan memperhatikan serta menerima saran dari pelanggan sebagai bentuk evaluasi untuk perbaikan produk dan pelayanan yang dapat sesuai dengan selera klien. Variabel pembelajaran organisasi berpengaruh terhadap diversifikasi. Individu yang mempu mengintegrasikan kompetensi yang dia miliki dengan sumber daya yang dimiliki baik modal, manusia maupun modal intelektual serta peka terhadap permintaan konsumen yang beragam tidak ada salahnya mencoba memperluas bidang usaha guna menambah keuntungan. Variabel Kolaborasi usaha mempengaruhi Kinerja Bisnis, hendaknya pimpinanusahaWO melakukan kemitraan dengan organisasi lain dengan bidang yang terkait agar dapat lebih kompetitif di pasar dengan manfaat kualitas yang optimal.Variabel Diversifikasi usaha dan yang mempengaruhi Kinerja Bisnis. Pemenuhan kebutuhan klien secara lengkap memberikan nilai tambah suatu usaha WO dimataklien namun agar diversifikasi efektif baiknya memperluas bidang usaha yang masih terkait dengan bisnis WO.

Keterbatasan penelitian berikut ini adalahrespon rate rendah sebesar $55,12 \%$, hal ini mungkin disebabkan karena waktu penelitian yang kurang mencukupi dan lokasi obyek penelitian yang tersebar di jarak yang cukup jauh. Dari respon rate yang rendah tersebut berdamak pada jumlah sampel penelitian yang terlalu kecil mengingat perolehan sampel secara convenience. Selain 
itu,rendanya pengawasan ketika responden mengisi kuesioner mengingat pemilik usaha tidak selalu berada di tempat sehingga peneliti tidak melihat secara langsung proses pengisian angket kuesioner sehingga banyak pertanyaan terbuka yang tidak diisi.

Model penelitian masih sangat sederhana dan butuh pengembangan lebih lanjut karena faktor yang dapat meningkatkan kinerja bisnis masih berpeluang luas untuk diteliti diluar faktor yang digunakan dalam penelitian.

\section{DAFTAR PUSTAKA}

Barney, J. B. (2001). "Resource-based theories of competitive advantage: A tenyear retrospective on the resource-based view." Journal of management, 27(6), 643-650.

Bandura, A., \& Walters, R. H. (1977). Social learning theory (Vol. 1). Englewood Cliffs, NJ: Prentice-hall.

Fathor A.S1, Mohammad Arief. (2017). "Pembelajaran Organisasi UKM untuk Menciptakan Keunggulan Bersaing." Jurnal Ekonomi Modernisasi 13 (2) 2017, 105-118

Hashai, N. (2015). "Withinindustry diversification and firm performance-an S-shaped hypothesis.” Strategic Management Journal, 36(9), 1378-1400.

Kurniawan, A. (2012). "Pengaruh Pembelajaran Organisasi terhadap Kompetensi, Tingkat Diversifikasi dan Kinerja STAIN Swasta di Wilayah III Cirebon." Holistik, 13(2).

Firdayanti, R., Miyasto., \& Soegiono (2017). "Pengaruh Orientasi Kewirausahaan dan Pembelajaran Organisasional Terhadap Kualitas Aset Stratejik Dalam Meningkatkan Kinerja Bisnis (Studi Pada UKM Batik Semarang)." Jurnal Anthropologi Sosial Vol 2 No.1. ISSN: 2597-9892.

Hasan, A., Fithri, P., Annisa, I.Q. (2017). "Pengaruh Kemampuan Pembelajaran Organisasi Terhadap Kinerja Industri Menengah Bidang Pangan di Kota Padang." Prosiding SNTI dan SATELIT 2017 (pp. F215-222).

Hidayat, H (2013). Aliansi Strategis Dalam Membangun Keunggulan Kompetitif Usaha Kecil Menengah di Indonesia.

Hitt, M. A., Tihanyi, L., Miller, T., \& Connelly, B. (2016). "International diversification: Antecedents, outcomes, and moderators." Journal of Management, 32(6), 831-867.

https://www.kominfo.go.id/content/detail/11526/kemenkop-ukm-379-juta-umkmsudah -go-online/0/sorotan_media, diakses 23 Mei 2018, pukul 12:41.

Mustikowati, R. I., \&Tysari, I. (2015). OrientasiKewirausahaan, Inovasi, dan Strategi Bisnis untuk Meningkatkan Kinerja Perusahaan (Studi pada UKM Sentra Kabupaten Malang). Jurnal Ekonomi Modernisasi, 10(1), 23-37. 
Nugraha, A.W., (2017). "Pengaruh Aliansi Strategis dan Pembelajaran Organisasi Terhadap Keunggulan Bersaing dan Implikasinya Pada Kinerja Perusahaan (Studi Kasus Pada Sentra Industri Kaos dan Sablon Cuci Kota Bandung).” Jurnal Manajemen Bisnis Vol 1. No 1.

Rani, A. E., Baihaqi, I., \&Bramanti, G. W. (2017). “Analisis Pengaruh Atribut Kemitraan Terhadap Kolaborasi dan Kinerja Pada Industri Food service Di Surabaya." Jurnal Sains dan Seni ITS, 6(2), D263-D266.

Sari, I. A., Wiratno, A., \&Suyono, E. (2014). Pengaruh Strategi Diversifikasi dan Karakteristik Perusahaan Terhadap Kinerja Perusahaan. Journal of Auditing, Finance, and Forensic Accounting, 2(1), 13-22.

Satoto, S. H. (2009). "Strategi diversifikasi terhadap kinerja perusahaan.” Jurnal Keuangan dan Perbankan, 13(2), 280-287.

Sirait, M.L., Sukmawati, A., \& Sumertjaya, I.M. (2015). "Pengaruh Organisasi Pembelajar dan Inovasi Terhadap Peningkatan Kinerja UKM di Kota Bogor.” Jurnal Manajemen, Volume XIX, No. 02, Juni 2015: 290-303.

Tjiptono, F. (2016). "Kelanggengan Entrepreneurship dalam Bentuk Bisnis Keluarga: Apa yang Telah dan Masih Perlu Diungkap." Jurnal Entrepreneur dan Entrepreneurship, 2(1, 2), 1-12.

Visnjic, I., Wiengarten, F., \& Neely, A. (2016). "Only the brave: Product innovation, service business model innovation, and their impact on performance.” Journal of Product Innovation Management, 33(1), 36-52. 